\title{
Impact of the AEC on Migrant Workers: A Case Study of the Rohingya in Khon Kaen Thailand
}

\author{
Mahmood Hayeemad \\ College of Islamic Studies, Prince of Songkla University, Pattani Campus \\ Thailand
}

Rathakarn Buasri (Corresponding author)

Faculty of Business Administration Khon Kaen University, Nong Khai Campus

Thailand

Received: June 26, 2015 Accepted: August 5, 2015 Published: August 20, 2015

doi:10.5296/jad.v1i1.7928 URL: http://dx.doi.org/10.5296/jad.v1i1.7928

\begin{abstract}
There are several researches in Myanmese nevertheless they never concern Rohingya migrant workers. Because the ASEAN is going to become AEC in 2015, they can migrate freely in the region and National Treatment. The aim of this research is to study how AEC affects to Rohingya workers in Khon Kaen Thailand by qualitative research approach, sample selection with Snowball sampling, and in-depth interview, the limitation is interview only 11 sample. This study demonstrate awareness of AEC effects and find the workers have very less knowledge about AEC, in addition every Rohingya workers express that there is no effect from ASEAN community because they do not have Myanmese identity card and never be Myanmar nationality. Every migrant would not like to go back to Myanmar because there is not confident that the Myanmese government recognizes Rohingya as the Myanmese. In contrast, they hope the government's merciful operations to provide citizenship as right as the one of Myanmese.
\end{abstract}

\section{Introduction}

The international migrant workers are the biggest group that has mostly affected to the global socioeconomic system (Archavanitkul, 1997). Thailand has depended on foreign workers for over a decade and will likely be employing unskilled migrants for coming years, which suggests that the government should acknowledge a structural dependence on migrants by the 
ASEAN labor ministers to recognize that migration for working is likely increase in volume and diversity over the next decade. In addition, they have endorsed that creation of an ASEAN Institute for Migration Studies to help developing mutually beneficial migration for employment policies (Martin, 2003).

In 2015, ASEAN will become an ASEAN Economic Community (AEC) Consists of three main pillars 1) ASEAN Political-Security Community. 2) ASEAN Economic Community 3) ASEAN Socio-Cultural Community. The ASEAN Charter (ASEAN Charter) is a framework or fundamental law. Further the aims of the ASEAN Community are; 1) Single Market and Production Base -free flow of goods, free flow of services, free flow of investments, free flow of capital and free flow of skilled labor. 2) High Competitive Economic Region, to build capacity in various areas such as competition policy, intellectual property rights, tax policy and infrastructure development. 3) Equitable Economic Development, the economic integration of its members and reduce gap of development between old and new members, such as support for the development of SMEs. 4) Integration into Global Economy -Integration into the international community, focusing on the coordination of economic policy with countries outside ASEAN, such as preparation of a free trade area, construction a network of production and distribution etc. (Termpittayapaisith, 2011).

There is acknowledge that Thai economy's dependence on migrants is likely to persist in the medium term, develop the socio-economic justification for employing migrants, and explain to Thai employers and workers, as well as migrants and Thai society, the economic benefits of migrant workers (Martin, 2003).

There were 5,301 immigrant workers, who were allowed working in Khon Kaen Province in February, 2012. In these numbers, there were 3,200 workers with lawful, and others $(2,101$ workers) were illegal workers, and have been permitted to work temporarily by Cabinet. Moreover, there are 1,563 who are Myanmese workers (74.39\% illegal workers, Khon Kaen Provincial Employment Office, 2012). The unskilled migrants are mostly unauthorized foreigners from neighboring Myanmar 80-90 per cent of the total, Laos, and Cambodia. The Thai employers were allowed to register them several times, and registration allowed them to work legally by postponing their removal from Thailand (Martin, 2003).

There are several ethnic in Myanmar, the real Myanmese people who are the most is called Barmar, and around them with other races such as Chin, Kachin, Kayah, Mon, and Rakhine. Therefore, there is rather no harmonious to be a union in Myanmar (Indochina Studies Center, 2009). The real Myanmar is three-forth from overall population and have right to govern the country and career more than other races. Although the government has announce to provide parallel right for every ethnic, but there is unchanged in practice or even adjust the approaches (Playchomphu, 2006). Yakhai, the ethnic settle between the east cost of Bengal bay and the Arakan Mountain nearby Bangladesh, which it rather is a free state (Playchomphu, 2006). The Rohingya is an ethnic in Yakhai, Arakan state, bay in northern of Myanmar nearby southern border of Bangladesh, is an unacceptable ethnic by Myanmese government because their forefathers were herded by British from Bangladesh for joint wars or to be British's servants within the wars. Therefore, the Myanmese government never 
accepts and always pressures them, then they begun to move outside country for looking for new settlement either Thailand or Malaysia (The Nation News, 2009). The former governments tried to solve illegal alien workers from Myanamr, Lao, and Cambodia by set policies to alleviate them livable and work temporarily in Thailand under government's conditions since 2535 until nowadays. The alien illegal worker management is a form of committees to manage them along with international negotiation for proven nationality and legally work (Komkay, 2009). The suggestion from research topic migrant domestic worker: from Burma to Thailand were, the Asian conference should talk about migrant workers in every industry issue and consider particularly complicated situation relevance Myanmese migrants (Punpuing, 2005).

Under The Master plan on ASEAN Connection in ASEAN Socio-culture Community, the goal is for unity, generosity, good living, development, and social stability in ASEAN by eliminate poverty, create social safety network, and protect the right of underprivileged or migrant workers (Termpittayapaisith, 2011). In addition, there is going to become AEC in 2015, which the workers able to move to anywhere in the region and National Treatment (The Federation of Thai Industries. 2011). Therefore, I would like to study in ASEAN community and how affect against Rohingya workers in Khon Kaen to create the approaches to manage them in the future.

\section{Conceptual Background}

Migration is defined broadly as a permanent or semi-permanent change of residence. No restriction is placed upon the distance of the move or upon the voluntary or involuntary nature of the act, and no distinction is made between external and internal migration (Everett S. Lee,1966). The people who especially emigrate across borders without nationality, are affected in order to alive and every opportunity part of life. (Archavanitkul, 2002). The definition of alien workers who stealthy emigrate across country is, foreigners who move across country illegal and work without permission to live in that country (Archvanitkul, 2002) Working of Aliens Act B.E. 2521 section 5 "Alien is individuals who are not Thai nationality”. According to Rule of Prime Minister's Office in order to alien stealth worker management B.E. 2544 and B.E 2546 ( $2^{\text {nd }}$ rule) “ Alien stealth worker is Myanmese, Laos, and Cambodian who move to Thailand and break the laws concern immigrant with working purpose by mainly laborious (Department of Employment, 2007).

The Laws of Migration are; Ravenstein, (1885) 1) The great body of our migrants only proceed a short distance, and that there takes place consequently a universal shifting or is placement of the population, which produces "currents of migration" setting in the direction of the great centers of commerce and industry. 2) The inhabitants of the country immediately surrounding a town of rapid growth, flock into it the gaps thus left in the rural population are filled up by migrants from more remote districts, until the attractive force of one of our rapidly growing cities makes its influence felt, step by step, to the most remote corner of the kingdom. 3) The process of dispersion is the inverse of that of absorption, and exhibits similar features. 4) Each main current of migration produces a compensating counter-current. 5) Migrants proceeding long distances generally go by preference to one of the great centers 
of commerce or industry. 6) The natives of towns are less migratory than those of the rural parts of the country. 7) Females are more migratory that males.

Factors in The Act of Migration, which enter into the decision to migrate and the process of migration, may be summarized under four headings, as follows: 1. Factors associated with the area of origin. 2. Factors associated with the area of destination. 3. Intervening obstacles. 4. Personal factors (Everett S. Lee, 1966).

Characteristics of migration are; 1. Migration is selective. 2. Migrants responding primarily to plus factors at destination tend to be positively selected. 3. Migrants responding primarily to minus factors at origin tend to be negatively selected; or, where the minus factors are overwhelming to entire population groups, they may not be selected at all 4. Taking all migrants together, selection tends to be bimodal. 5. The degree of positive selection increases with the difficulty of the intervening obstacles. 6 . The heightened propensity to migrate at certain stages of the life cycle is important in the selection of migrants. 7. The characteristics of migrants tend to be intermediate between the characteristics of the population at origin and the population at destination (Everett S. Lee, 1966).

Battistella and Skeldom (1999) (reference in Archavanitkul, 2003) divided illegal migrations in Asia into 3 categories as; 1) undocumented migration, 2) overstay migrations, 3) immigrant workers without working permission In addition, there are 2 categories of unlawful stealthy alien workers as; 1) aliens were born in Thailand without Thai nationality, and 2) aliens moved to Thailand without permission. Nevertheless, in order to Nationality Act and Immigration law that is divided into 3 categories as; 1) aliens were born in Thailand, 2) aliens settle in Thailand, 3) aliens temporary live in Thailand (Archavanitkul, 2003). However, Archavanikul (2000) described Myanmese migrants in Thailand into 6 groups as; 1) Myanmese displaced persons, 2) runaway from Myanmar, 3) displaced persons because wars, 4) students, 5) persons who are documented migrants, and 6) illegal migrants for work.

Impacts of Migration are; human migration affects population patterns and characteristics, social and cultural patterns and processes, economies, and physical environments. As people move, their cultural traits and ideas diffuse along with them, creating and modifying cultural landscapes (National Geographic Society, 2005).

Push pull migration law, we can formulate the migration process as the resultant of a "push" factor and a "pull" factor, but must discount this combination by distance deterrence between the places. The push factors are those life situations that give one reason to be dissatisfied with one's present locale; the pull factors are those attributes of distant places that make them appear appealing (Dorigo, 1983). In addition, people move for a variety of reasons. They consider the advantages and disadvantages of staying versus moving, as well as factors such as distance, travel costs, travel time, modes of transportation, terrain, and cultural barriers. Push factors is reasons for emigrating because of a difficulty such as a food shortage war flood etc.; Pull factors is reasons for immigrating because of something desirable such as a nicer climate, better food supply, freedom, etc. (National Geographic Society, 2005).

The main causes of immigration are the different of economic growth, population structure, 
political conflicts, environmental and natural conditions in individual country; government's policies either support or not support migration. The importance factors support immigration are information from media, comfortably communication, migration network as family or friends who move before, international traffic person organization that is criminal along with international vipers (Archavanitkul, 1997).

\subsection{Regulation of Migrant Worker in Thailand}

The Royal Decree 281 of November 24, 1972 reserves most jobs for Thais; Article 12 opens 27 occupations that were open to foreigners. The foreigner Employment Act of 1978 specified 27 occupations that were open to foreigners, but Article 17 allows the Thai Cabinet to permit foreigner to enter and stay in Thailand as an exception to the general bar. Article 17 has been the basis for Thailand's policy toward unskilled migrant in the 1990s, and the migrant registration exercises in 1992, 1996, and 2001. Each registration exercise had amendments and extensions (Martin, 2003). According to the Cabinet in 2011, firstly to extend for alive of migrant workers' citizenship even Burmese, Lao, and Cambodia workers have been temporarily permitted on 19 January 2010 to 14 June 2012. Second, to proof workers' nationality must be completed by 26 April, 2011 but no later than 14 June 2012 . Third, there must reduce visa's fee from THB 2,000 to THB 500 within 4 years. Fourth, extend to collect money into a fund for send aliens outside Thailand for 1 year. (Prachachat, 2012).

\section{Literature Review}

\subsection{Causes of Migrate to Thailand}

The causes of firstly migrate for work in oversea by Myanmese workers are issues in working or revenue, or issues about family (Wongboonsin, 2001). In addition, wars and government's policies that speed up to economic crisis and family crisis also be the causes of it (Punpuing, 2005). Furthermore, the most of Myanmese migrant workers are driven by the difficulties of life in Myanmar. They are mostly from very poor families that have no money, job, electricity, or even the vehicle the vehicle that can take them to the hospital when they are in need of medical care (Khaopanya, 2011). Tungmanakong (2009) argued that the main reasons that encouraged them to illegally enter in to Thailand were the danger of lives and property, because of Myanmar internal fighting, jobless and poverty. The economic, society and culture in Thailand (Ranong Province) were satisfied the needs of Myanmar workers, especially on physiology, mentality and society were more satisfied than the satisfied needs of such factors from their country (Jaivai, 2001).

Moonla (2010) found the majority of migrant labors were leaving home countries for the reason of political unrest situations and the consequential socio-economic instability and insecurity at home. Most of Myanmar migrant laborers decided to seek employment in Thailand because of the economic problems in Myanmar and the wish to escape from the warfare danger in home country. Factor influencing the decision of those migrant laborers to come to Thailand are the push factor from Myanmar domestic economic problems and warfare, and the pull factor from better economic situation and opportunity in Thailand 
(Archa, 2007). In addition, the push factors driving migrant workers to seek employment in Thailand, a destination country, include economic conditions, strict control of migration and political situation while the pull factors attracting their migration include availability of unsought-for work, better earning in Thailand, easy border crossing and inadequate control at the border by government officials (Neaungchompho, 2007).

\subsection{The Ways and Approaches to Thailand}

The most migrations are done through a broker system. Boarder points are always used at the crossing bridges to Myanmar at Mae-Sai District in Chiangrai Province, and at Mae-Sod District in Tak Province and by car (Khaopanya, 2011). In addition, the migrants have to pay too much in advance for migrate, or become owe to sender (Punpuing, 2005). Archavanitkul, (2000) demonstrated the most of migrants have moved to Thailand without agents' operating, in addition they do not go back to Myanmar and never contact to their family in their hometown, further they live in only one province and have never been in other province.

\subsection{Problems Affect to Migrant Workers}

Most migrations cannot speak Thai and some of them still have problem with working permission, it raised their cost of living expenses higher than it should be (Khaopanya, 2011). Punpuing (2005) found 48\% of them had faced to Thai officers and half of then expressed that Thai officers want money, and $30 \%$ of them was bluffed to send them back to Myanmar. The language difficulty is always increase worse relationship between employers and employees, further employees are always attacked and upset. Furthermore, there is limited to adapt into Thai society because their illegal status, therefore they have less Thai friends and unskillful speak Thai. The main causes are living and working quite separate from Thai (Archavanitkul, 2000).

The illegal crossing into Thailand had encountered the rip off by agents or middleman, worsened working conditions, cruelty, sexual harassment, violent treat by the authorities, ethnical bias, and all sorts of danger during the entering process (Tungmanakong, 2009).

Moonla (2010) proposed that there are both negative and positive impacts of the migrant labors identified. The negative consequences were evident in term of environment, public health, education safety in life and property, narcotic drugs, the alien feeling with other ethnic. The positive social effect could be seen in the aspect of local art, and tradition conservation. The contributive economic effects were found in the greater investment and money circulation in local economy and the mitigation of local labor shortage, while the undesirable consequences were the competing demand for job with the domestic workers, the outflow of Thai money, and the weakening bargaining power of the domestic labors. The political effects were in the negative nature only namely the opportunity for dishonest practices and the potential to get political conflict with neighboring country in the future.

Furthermore, to generate socio-economic implications on the local community, economically, foreign currencies were transferred out of Thailand and wage rate for Thai labor were reduced to the level paid to migrant workers. Subsequently, the money for local circulation was reduce and Thai family livelihood because worse due to job loss to migrant workers. 
Socially, Myanmar migrant labors appeared to be the source of problems about smuggling, disturbing peace and order, and public health (Archa, 2007).

\section{Research Method}

The empirical basis of this paper is the qualitative field research; the main topic of the in-depth interview are; 1) Causes and approaches to Khon Kaen, Thailand. 2) Legal status of Rohingya's workers. 3) Rohingya's awareness concern with ASEAN community. 4) The AEC affect to Rohingya workers.

This research is covered time period from February - April 2012; the field research had two crucial limitations, the first being sample size and quality. The main data sources were in-depth interviews with 11 Rohingya workers in Khon Kaen, because of the resource limitations snowball sampling was chosen as the means of finding informant, the first informant as recommended by a leader of Muslim in community (Imam). The second limitation is the analysis method. As it relies mainly on a relatively small number of informants, this paper does not and cannot provide statistical data on and quantitative analysis of the research problem. The research should be treated as pilot-research for further study.

\section{Result}

For this research, much of Rohingya workers are male, average 40 years old, muslim, marriage status and someone marriage with Thai female, alive in Thailand more than 20 years, the occupation is seller with sale Roti, and rather good for communicate in Thai.

\subsection{Causes and approaches to Khon kaen}

The sample provides the same information as the Myanmese government does not recognize them as one of Myanmese and be pressured from the government's military. Therefore, they decide to emigrate through Mae Sod, Tak province, in addition they get the job through agent. Much of them are employed by sale roti in Northeastern province such Nakhonratchasima or Khonken.

The 48 years old Rohingya who sells roti and good for speak and listen Thai, marriage with Thai female said "I was oppressed from Myanmese military while I lived there, so I had to used fake passport to came to Thailand in 1988 by Maesod border, Tak province. I had to paid THB 1,500 to agent for get the job and owed the employer THB 5,000 for invested in instruments for sale roti in Nakhonratchasima. I could pay the debt within 6 months and moved to Khonken for sale roti”.

\subsection{Legal status of Rohingya's workers}

Much of Rohingya workers in Khon Kaen have registered to government's employment agency and some of them as during prove to Myanmese nationality. Every Rohingya have to pay venality cumulatively at least THB 2,000 per month to government officers.

"I have migrant worker card and I have to pay at least 2,000 Baht to government monthly, while I have got average 200 Baht per day from sale roti". The expression from the 42 years old Rohingya who sale roti and able to listen, speak, read, and write Thai, and used to 
marriage with Thai female.

\subsection{Rohingya's awareness concern with ASEAN community}

Every Rohingya workers aware Myanmar is one of ASEAN community, but they know less about the effects of AEC, right of workers' movement, they should be treated same their citizen by individual government. In addition, I find that they usually watch television for entertain rather than other purpose, but they still get information concern with workers situations in Thailand and news within Myanmar from Rohingya association in Khon Kaen, which there is meeting every month. Furthermore, there are some workers recognize AEC in good level because they very good in Thai and receive news from newspaper and internet every day.

The 42 years old Rohingya who sell roti and listen, speak, read, and write Thai in good level said "I know AEC because I read newspaper every day, then I recognize Myanmar tries to open country for increase freely foreign investment form media. Myanmar has various resources and it will be more democratize than Thailand in the future. In order to ASEAN, critics from media said that Myanmese workers would go back to Myanmar increasingly, which means Thailand may lack the lowest employees in the future".

\subsection{The AEC Affects to Rohingya Workers}

There are freely movements of workers within ASEAN community. From interviewees that everyone agrees that ASEAN does not affect to Rohingya workers, because they do not become Myanmese and do not have identity card since they are born.

"The Myanmese workers may get any benefit from ASEAN community, but Rohingya workers get nothing from AEC because we did not get identity card since we are born, and the Myanmese government does not recognize us to be it citizen" The expression from the 42 years old Rohingya which sell roti and good for listen, speak, read, and write in Thai and used to marriage with Thai female.

The 48 years old Rohingya who sell roti, good in speak and listen in Thai, and marriage with Thai female said "If I am arrested and send to Myanmese government, I may kill myself cause it better than send me to the Myanmar government, because I would not like to be tormented in Myanmar".

\section{Discussion and conclusion}

Rohingya migrant workers in Khonken have came to Thailand around 20 years ago through Mae Sod border, Tak province. According to Khaopanya (2011), Myanmese workers have walked trough border at Mae San in Chiangrai, and Mae Sod in Tak because of able to walk through conveniently and concealable from Myanmese officers easier than others such as by sea.

Myanmese have moved to Thailand because there are wars and any government's policy to speed up the crisis (Panpuing, 2005), works and revenue (Wongboonsin, 2001). Further, the causes of Rohingya's movement are; they do not have identity card and Myanmese 
citizenship. Therefore they are pressured from Myanmese military government.

A lot of Myanmese workers cannot speak and read Thai (Khaopanya, 2011), although much Rohinya workers in Khonken able to speak and listen Thai, further some workers can read and write in Thai as these workers alive more than 20 years in Thailand. Surprisingly, I find that much of them cannot speak, read, and write in Myanmese because they use Rohingya language since they are borne.

Much of Myanmese aware that Myanmar is going to open the country and be one of ASEAN community, and get information from television, from monthly meeting at Rohingya association in Khonken. For awareness of AEC effects, I find the workers have very less knowledge about AEC, and every Rohingya workers express that there is no effect from ASEAN community because they do not have Myanmese identity card as they and their parents are born in Myanmar.

Every migrant do not want to go back to Myanmar because there is not confident that the Myanmese government recognize Rohingya as the Myanmese. In contrast, they hope to government's merciful operations to provide citizenship as other tribe in Myanmar, right as the one of Myanmese. Even if they receive the Myanmese citizenship, they still would like to alive in Thailand as the Myanmese in Thailand because they have lived so long time.

\section{References}

Archavanitkul, K. et al. (1997). Complicated and Complexity of Migrant in Thailand. Institute for Population and Social Research, Mahidol University.

Archavanitkul, K. et al. (2000). Sex, fertile hygiene and violent: Myanmese worker's experience. Institute for Population and Social Research, Mahidol University.

Archavanitkul, K. (2003). Status of knowledge migrant workers in Thailand and research consideration. Institute for Population and Social Research, Mahidol University.

Archa, P. (2007). Impact of Burmese Migrant Labour on Community's Economic and Social Development in Tambon Tha Sop Sao,Amphoe Mae Tha, Changwat Lamphun. Master of Arts (Political Economy), Changmai University.

Department of Employment and The Government Public Relations Department. (2007). The manual of migrant workers employment. Bangkok: P.P.S Kijjarean Co., Ltd.

Dorigo, G., \& Tobler, W. (1983). Push Pull Migration Laws. Annuals of The Association of American Geographer, 73(1), 1-17. http://dx.doi.org/10.1111/j.1467-8306.1983.tb01392.x

Everett, S. Lee. (1966). A Theory of Migration. Demography, 3(1), 47-57. http://dx.doi.org/10.2307/2060063

Ravenstein, E. G. (1985). The Laws of Migration. Journal of the Statistical Society of London, 48(2), 167-235. http://dx.doi.org/10.2307/2979181

Jaivai D., Lt.Cdr. (2001). The needs for Permanent Settlement in Thailand of Myanmar 
Workers: A Case Study of Ranong Province. Master of Arts (Social Development) Kasetsart University.

Indochina Studies Center. (2009). The Fundamental data of Myanmar. Graduate School of Public Administration, Burapha University.

Khaopanya, K. (2011). Myanmese Migrant Workers in Nakorn Isan Province The Northeast of Thailand. Master of Arts in Social Development, Khon Kean University. http://dx.doi.org/10.5481/kkujgs.2011.11.4.13

Komkay, S. (2009). Analyzing legal problems on management of illegal alien workers. Master of Laws, Dhurakij Pundit University.

Khon Kean Provincial Employment Office. (2012). Migrant Workers Management. Martin, P. (2003). Thailand: Improving Management of Foreign Workers. Bangkok, International Labour Office and International Organization for Migration.

Moonla, L. (2010). Migrant Labors and Socio-Economic and Political Effects in Mae Hong Son Municipality. Master of Arts (Political Economy) Changmai University.

National Geographic Society. (2005). Human Migration Guide. Retrieved March 2, 2012, from

http://www.nationalgeographic.com/xpeditions/lessons/09/g68/migrationguidestudent.pdf

Neaungchompho, P. (2007). Thai government guide lines on alien workers, B.E 2535-2548. Master of Labour and Welfare Development, Thammasart University.

Playchomphu, B. (2006). Myanmar: history, civilization and international relations. Bangkok: Odean Store.

Prachachat. (2012). Management of migrant workers, establish 5 nationality proof center. Retrieved April 18, 2015, from http://www.prachachat.net/news_detail.php?newsid=1334745016\&grpid=no\&catid=17

Punpuing, S. et al. (2005). Migrant Domestic Worker: From Burma to Thailand. Institute for Population and Social Research, Mahidol University.

Termpittayapaisith, A. (2011). "ASEAN Economic Community". Office of the National Economic and Social Development Board. Retrieved March 9, 2012, from http//www.secondary41.go.th/doc/Asian/prachakomAsian.PDF

The Nation News. (2552) "Rohingya" from migrant to Thai security crisis. Retrieved February 24, 2012, from http://www.backtohome.org./autopagev4/show_page.php?topic_id=2298\&auto_id=3\&Topic

The Federation of Thai Industries. (2011). "ASEAN Economic Community: AEC". Retrieved March 10, 2012, from http://www.fti.or.th/2011/download/technical/_263.pdf

Wongboonsin, P. et al. (2001). The effects of migrant workers' migration: a case study in Thailand. College of Population Studies, Chulalongkorn University. 


\section{Copyright Disclaimer}

Copyright reserved by the authors.

This article is an open-access article distributed under the terms and conditions of the Creative Commons Attribution license (http://creativecommons.org/licenses/by/3.0/). 